\title{
Cells in the Urine of Newborn Infants
}

\author{
HILTON SILVER, J. C. DREVER, and D. M. DOUGLAS \\ From the Royal Hospital for Sick Children, Edinburgh
}

Microscopical examination of urine is frequently carried out during the investigation of patients suspected of having a urinary tract infection, but the significance of cellular elements in the urine has always provided a stumbling block in the attempts to diagnose covert urinary tract infection. The estimation of the number of 'pus' cells in a high-power field has provided a variety of normal values ranging from 3 (Straffon and Engel, 1960), to 5 (Kass, 1956), to 20 per high power field (Michie, 1959). This method of counting is, however, prone to error: Stansfeld and Webb (1953), Stansfeld (1962), and Gadeholt (1964) have shown that variations in counts occur with inaccurate measurement of the volume of a 'drop' of urine, with varying thickness of urinary film being studied beneath the cover slip, and with centrifugation. Stansfeld and Webb (1953) claimed that the counting of pus cells found per unit volume of urine was a far more satisfactory procedure, and, even better, was the assessing of cells excreted in the urine per unit time, but this latter method was too time consuming for easy clinical application. There is, however, no agreed normal with regard to 'pus' cells/c.mm. of the urine, and, whereas Stansfeld and Webb (1953) and Stansfeld (1962) accept 'significant pyuria' as 10 or more leucocytes in an unspun sample of clean or catheter urine, James (1959) regarded 25 pus cells/c.mm. in males and up to $50 / \mathrm{c} . \mathrm{mm}$. in females as being acceptable as normal in a group of infants between the ages of 6 and 10 days. The problem of recognizing pus cells and differentiating them from small squamous epithelial cells and round epithelial cells has not received much attention. The use of dyes to stain the cells in urine has been suggested (Prescott and Brodie, 1964; Butterworth, 1966).

The purpose of this paper is to describe the observations made on urinary specimens collected within 36 hours of birth, obtained from 63 newborn infants. The differentiation of polymorphonuclear leucocytes, i.e. pus cells, from other cells found in the urine of newborn infants, is discussed.

Received January 5, 1967.

\section{Material and Methods}

Urine collections were obtained from healthy, fullterm infants within 36, often 24 hours of birth, there being 30 males and 33 females in the series. The specimens were collected in a Great Ormond Street Hospital urine collector (Model B). The $p \mathrm{H}$ of each specimen was estimated. Whenever a specimen was large enough in volume, $5 \mathrm{ml}$. were taken for centrifugation $(2100$ rev./min. for $10 \mathrm{~min}$.). In this way, whenever possible, paired specimens, spun and unspun, were examined in the standard way and compared. The spun specimen was prepared so that the cellular deposit was resuspended in $1 \mathrm{ml}$. supernatant. Much emphasis was placed on thorough mixing of the specimen, both centrifuged and uncentrifuged, before any attempts were made to study the cell populations.

Initially, all urines were stained using Quensel's methylene blue (Butterworth, 1966), in the belief that this would facilitate differentiation of the various cells in the urine, but staining was discarded after 10 specimens had been studied, and all the subsequent specimens were examined unstained.

Cells were divided into morphological groups, and the total cell counts were expressed in numbers per c.mm. urine, a Neubauer counting chamber being used for this purpose. The whole volume of the chamber $(0.9 \mathrm{c} . \mathrm{mm}$.) was scanned. The cells were classified according to morphology into polymorphonuclear leucocytes (pus cells), squamous epithelial cells (squames), and round epithelial cells (as seen in the basal layers of stratified epithelium of skin or cells lining the urinary tract). The numbers of unclassifiable cells were also recorded.

\section{Results}

The cells observed in the urinary specimens have been divided into pus cells and epithelial cells, the epithelial cells being classified, according to their morphology, into squames and round cells (Table I). In the 25 male infants, the polymorph count never exceeded 3 per c.mm., a total of 7 pus cells being seen in the 25 urinary specimens: the squames never exceeded 48 in any one patient, there being 170 cells in 25 specimens: the round epithelial cells similarly numbered 41 in the 25 specimens of urine. The number of cells where the morphology was distorted and unclassifiable was 31 cells in the group.

A similar analysis of specimens of urine from 
TABLE I

Range of Cells/c.mm. in Unspun Urinary Specimens

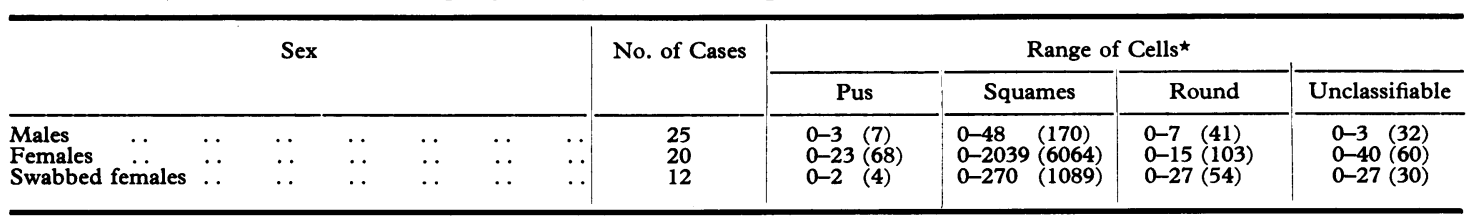

$\star$ Numbers in brackets in Tables I-IV represent total number of cells seen in each group.

TABLE II

Range of Cells/c.mm. in Centrifuged Urinary Specimens

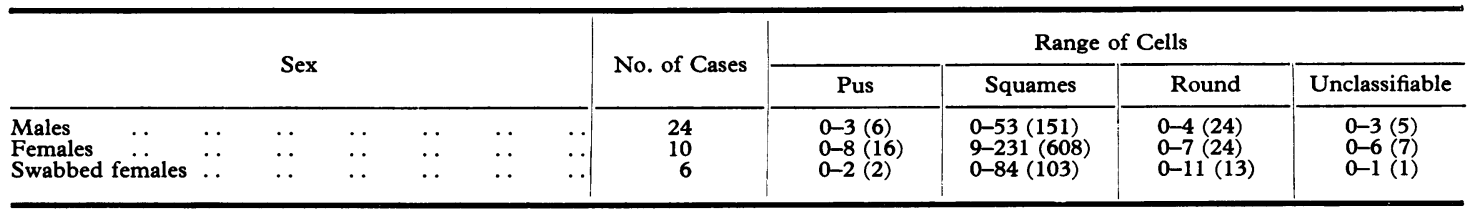

TABLE III

Urine Volumes and Cell Counts in 20 Unspun Specimens in Male Group*

\begin{tabular}{|c|c|c|c|c|c|}
\hline $\begin{array}{l}\text { Urine Volume } \\
\text { (ml.) }\end{array}$ & No. of Cases & $\begin{array}{c}\text { Pus Cells } \\
\text { (/c.mm.) }\end{array}$ & $\begin{array}{l}\text { Squames } \\
\text { (/c.mm.) }\end{array}$ & $\begin{array}{l}\text { Round Cells } \\
\text { (/c.mm.) }\end{array}$ & $\begin{array}{c}\text { Unclassifiable } \\
\text { (/c.mm.) }\end{array}$ \\
\hline $\begin{array}{r}3- \\
5- \\
10- \\
20-\end{array}$ & $\begin{array}{l}4 \\
5 \\
5 \\
6\end{array}$ & $\begin{array}{c}0-1(2) \\
0 \\
0-3(3) \\
0-1(1)\end{array}$ & $\begin{array}{l}0-38(44) \\
0-8(8) \\
1-7(14) \\
0-9(20)\end{array}$ & $\begin{array}{l}0-5(7) \\
0-2(2) \\
0-1(1) \\
1-17(17)\end{array}$ & $\begin{array}{l}0-1(2) \\
0-1(1) \\
0-2(3) \\
0-4(10)\end{array}$ \\
\hline
\end{tabular}

* 5 cases not included because urinary volumes in these were not recorded.

female infants revealed that the polymorph count reached 23 in one urine, there being a total of 68 polymorphs seen in 20 urines. The squame population was much increased as compared with the males, one specimen containing 2039 cells, and there was a total of 6064 cells in 20 specimens. The round epithelial cell count of 103 in 20 specimens included one specimen containing 15 cells (where the associated squame count was 128). There were more unclassifiable cells in the female group ( 60 cells in 20 infants). In order to assess the significance of the vulval and vaginal cellular secretions on the urinary cell population, 12 further cases were examined, where the vulva and perineum were cleaned with saline-soaked cotton wool swabs before the urine collection was made. In the swabbed group, a maximum of 2 pus cells (4 cells in 12 cases), up to 270 squames (1089 cells in 12 cases), up to 27 round cells of epithelial type (54 cells in 12 cases), and 30 unclassifiable cells in the 12 cases, were found.

In those cases where paired urines were available, spun specimens were studied for comparison (Table II). In the 24 males, a total of 6 pus cells $/ \mathrm{c} . \mathrm{mm}$. (range $0-3 /$ c.mm.) was seen: the other cells comprised 151 squames (the highest number in one specimen being 53), 24 round epithelial cells, and 5 unclassifiable cells. 10 spun specimens were obtained from the female group, where the highest pus cell count was $8 / \mathrm{c} . \mathrm{mm}$. ( 16 cells in 10 specimens): here, the squames varied between 9 and 231 (608 in 10 specimens), and round epithelial cells numbered 24 in 10 specimens: in this group, there was a total of 7 unclassifiable cells. We were able to centrifuge 6 specimens from the swabbed cases for comparison. Here the total counts per c.mm. were 2 pus cells, 105 squames, 11 round epithelial cells, and 1 unclassifiable cell.

In the males, comparison of volumes of spun urine with the cell count revealed no obvious inverse proportional change in pus cells, squames, or epithelial round cells (Table III).

In the females, there tended to be a larger count of squames in the smaller volumes of urine, suggesting that this volume had been 'contaminated' by vulvo-vaginal secretions (Table IV); this inverse relation is also apparent with the pus cell counts but is not seen with the round epithelial cell group, where the majority of cells are probably from the renal tract.

In all those cases where the pus cell count is $3 /$ c.mm. or more, other cell types in the respective 
TABLE IV

Urine Volumes and Cell Counts in 14 Unspun Specimens in Female Group ${ }^{\star}$

\begin{tabular}{|c|c|c|c|c|c|}
\hline $\begin{array}{l}\text { Urine Volume } \\
\text { (ml.) }\end{array}$ & No. of Cases & $\begin{array}{c}\text { Pus Cells } \\
\text { (/c.mm.) }\end{array}$ & $\begin{array}{l}\text { Squames } \\
\text { (/c.mm.) }\end{array}$ & $\begin{array}{l}\text { Round Cells } \\
\text { (/c.mm.) }\end{array}$ & $\begin{array}{l}\text { Unclassifiable } \\
\text { (/c.mm.) }\end{array}$ \\
\hline $\begin{array}{r}3- \\
5- \\
10- \\
20-\end{array}$ & $\begin{array}{l}9 \\
2 \\
2 \\
1\end{array}$ & $\begin{array}{c}0-7(35) \\
0-23(23) \\
0 \\
0-3(3)\end{array}$ & $\begin{array}{l}8-1850(9998) \\
0-128(128) \\
0-132(132) \\
0-38(38)\end{array}$ & $\begin{array}{l}0-10(31) \\
0-15(15) \\
5-9(20) \\
0-14(14)\end{array}$ & $\begin{array}{l}0-40(40) \\
0-4(4) \\
0-1(1) \\
0-3(3)\end{array}$ \\
\hline
\end{tabular}

* 6 cases not included because urinary volumes in these were not recorded.

TABLE V

High Pus Cell Counts and Epithelial Cell Counts

\begin{tabular}{c|c|c|c|c}
\hline $\begin{array}{c}\text { Pus Cells } \\
\text { (/c.mm.) }\end{array}$ & Sex & $\begin{array}{c}\text { Squames } \\
\text { (/c.mm.) }\end{array}$ & $\begin{array}{c}\text { Round Cells } \\
(/ \text { c.mm.) }\end{array}$ & $\begin{array}{c}\text { Urine } \\
\text { Volume (ml.) }\end{array}$ \\
\hline 3 & $\mathrm{~F}$ & 40 & 3 & 1 \\
6 & $\mathrm{~F}$ & 47 & 4 & $?$ \\
23 & $\mathrm{~F}$ & 128 & 15 & 5 \\
12 & $\mathrm{~F}$ & 2039 & 3 & $2 \cdot 5$ \\
17 & $\mathrm{~F}$ & 609 & 10 & $1 \cdot 5$ \\
\hline
\end{tabular}

urines are compared (Table V); the increased pus cell count is associated with a high count of squames, particularly where the pus cell count is over $10 / \mathrm{c} . \mathrm{mm}$. The round epithelial cell count does not show a definite relation, the count being low $(3 / \mathrm{c} . \mathrm{mm}$.) when the squame count is high $(2039 / \mathrm{c} . \mathrm{mm}$.). The proportionate increase in pus cells in specimens of high squame content, again suggests the role of 'contamination' of vulvo-vaginal secretion, since every case in the Table having a high pus cell count was found to be a specimen taken from a female.

\section{Discussion}

The importance of pyuria as a significant indication of urinary tract infection tends to be minimized because of (1) the difficulty in distinguishing pus cells from the small round epithelial cells in the urine, and (2) the lack of agreement as to the numbers of pus cells which may be found in any urine.

Initially we attempted to distinguish pus from other cells by staining urine, using Quensel's methylene blue: the peroxidases in the living polymorph cytoplasm bring about a decolorization of the blue stain, leaving the cytoplasm clear, while the granules and nucleus remain deep blue. However, with diminishing enzyme activity, the cytoplasm of the pus cell begins to take up the dye in small amounts, resulting in equivocal cytoplasmic staining. The problem of pus cell differentiation is thus reintroduced. For this reason, we discarded staining of the urine as an unsatisfactory means of recognizing urinary pus cells. A more complex form of stain, as used by Prescott and Brodie (1964), rendered the process of staining more difficult.
However, it became increasingly apparent to us that cells in the urine could be distinguished by morphological features only, and that stains were unnecessary. Cells that appeared unclassifiable were few in number. Because the unclassifiable group represents old and degenerated cells, and since the pus cells that appear in the urine associated with urinary tract infection still retain enzyme activity, the unclassifiable group almost certainly consists mainly of the different forms of epithelial cell.

The polymorphonuclear leucocytes undergo changes when exposed to urines of varying specific gravity, osmolality, and $p \mathrm{H}$. The cell contour usually remains rounded and the granules obvious (Fig. 1): often, however, the multilobed nucleus

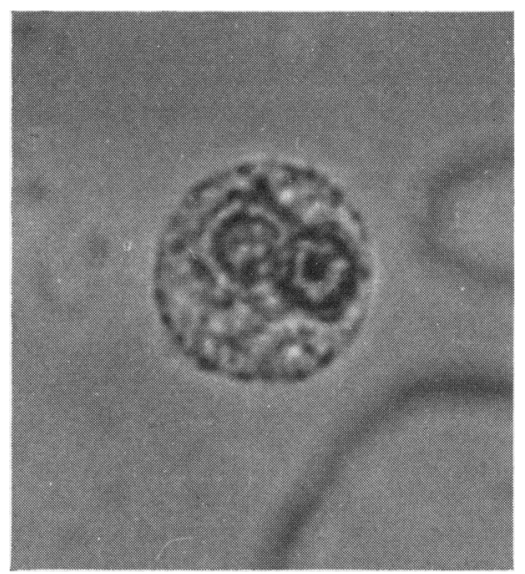

Fig. 1.-Pus cell shows multilobed nucleus with granular cytoplasm. $(\times 1250$.

appears as a single mass due to shrinkage and aggregation of the lobes (Fig. 2): the nucleus is sometimes completely obscured by the cytoplasmic granules. Cell diameter is usually smaller than the pus cells seen in blood films. In urines of low specific gravity, pus cell diameters can be large, due to swelling of the cell membrane in the hypotonic solution: in these cases, the pus cell diameters 


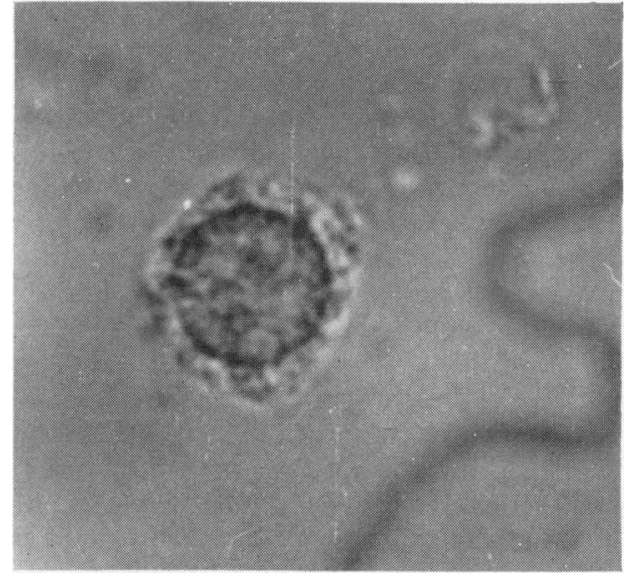

FIG. 2.-Pus cell shows aggregation of nuclear lobulations, giving the appearance of a dense nucleus. ( $\times 1250$.

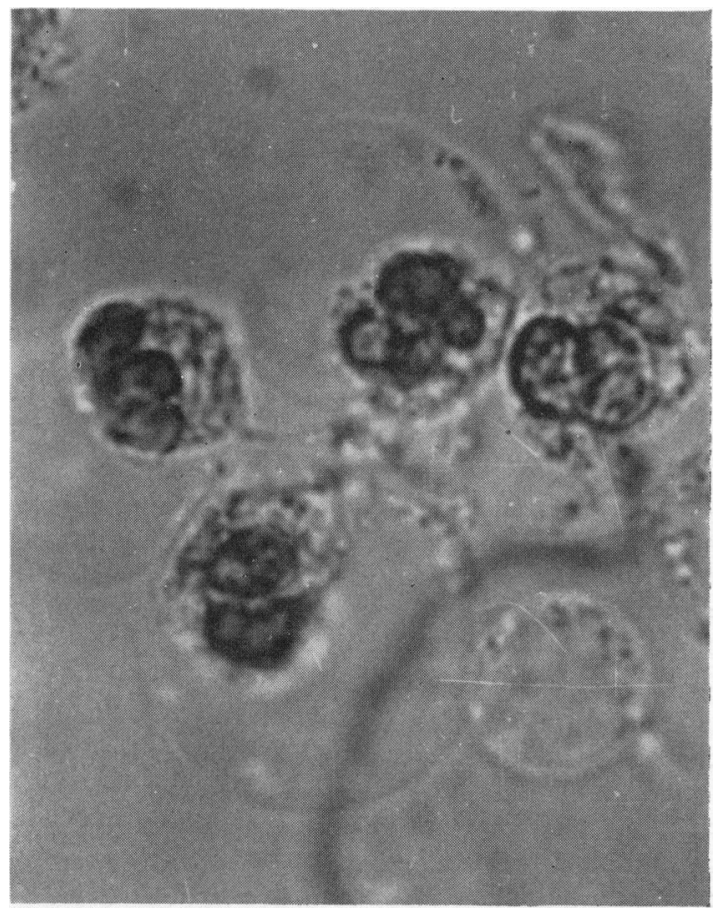

Fig. 4.-Group of swollen pus cells. (× 1250.)

may equal those of medium-sized squame cells (Fig. 3 and 4). Two features that were found to be very helpful in distinguishing pus cells from epithelial round cells, were the presence of brownian movement of the cytoplasmic granules (McLeod and McLeod, 1959), and the presence of motile phagocytosed bacteria in the cytoplasm, neither of these features occurring in the epithelial cells.

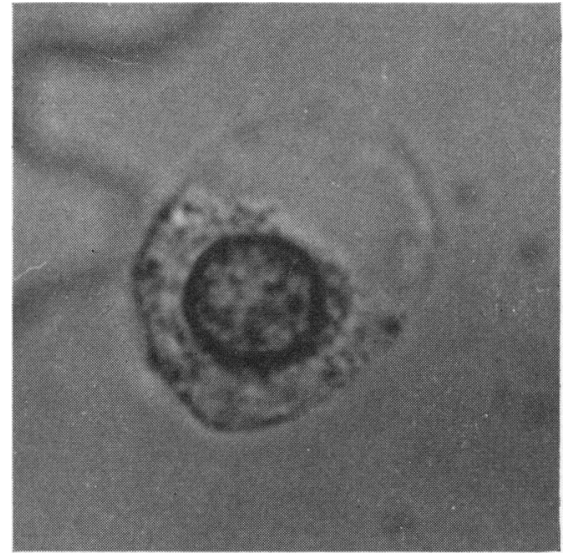

FIG. 3.-Pus cell shows swelling of cell membrane with increase in cell size. The cell wall has torn free from the cytoplasm. Note that the nucleus appears single. ( $\times$ 1250.)

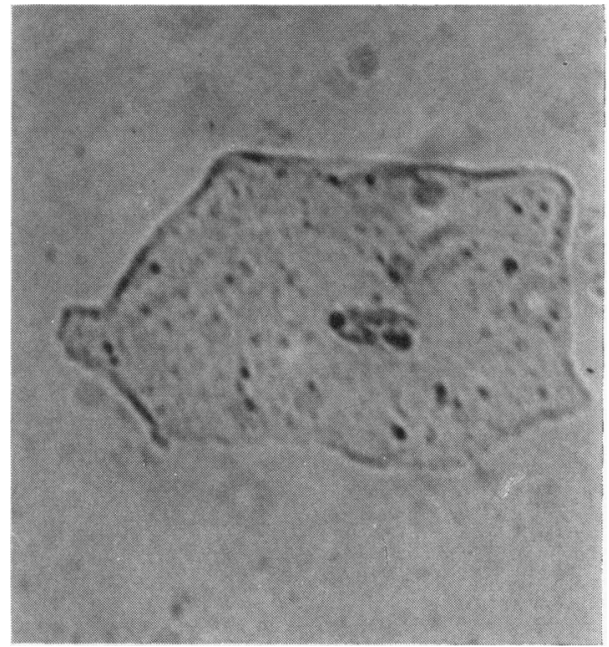

Fig. 5.-Squame cell showing small nucleus and finely granular cytoplasm. Cell shape is characteristic. ( $\times$ 1250.)

Cells that could possibly be mistaken for pus cells are the small round squames and the round epithelial cells, most of which arise from the urinary tract. The squames have a small nucleus with a fairly dense chromatin network, the cytoplasm being finely granular (Fig. 5 and 6): the round cells are round or oval, with a large round nucleus and fine chromatin, the cytoplasm being homogenous with a few small granules (Fig. 6 and 7).

In all the infants investigated, the urinary $p H$ remained between 5 and 7 , the majority of specimens being 6 . 


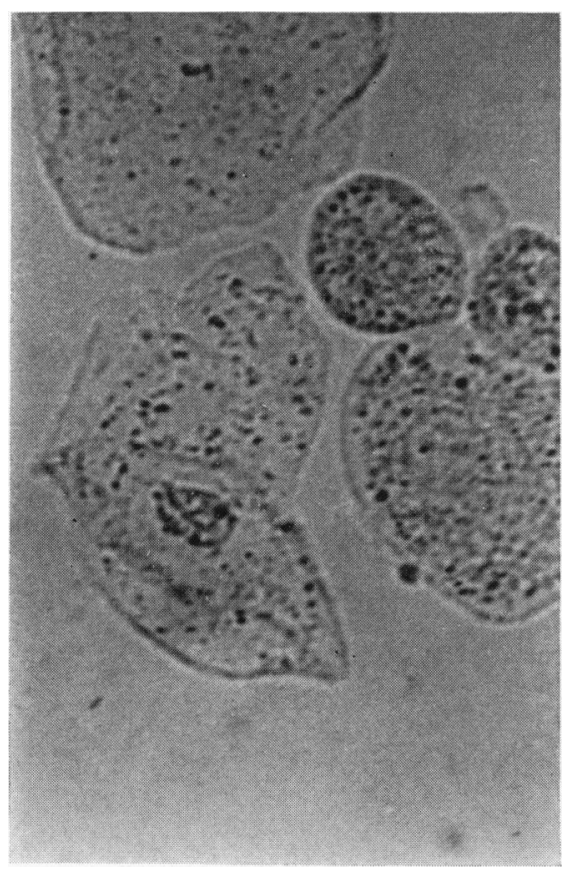

Fig. 6.-Group of squames and round epithelial cells. $(\times 500$.

The highest number of pus cells seen in any one of the urines in the male group was $3 / \mathrm{c} . \mathrm{mm}$.: this applied equally to spun and unspun specimens, and,

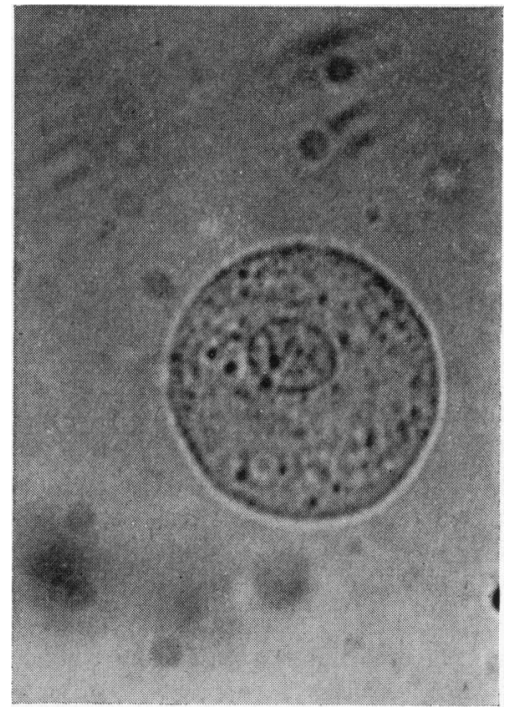

FIG. 7.-Round epithelial cell showing large round nucleus with fine reticulation. The cytoplasm is finely granular. $(\times 1250$. out of 29 specimens, 24 contained no pus cells at all $(83 \%)$. There appeared to be a greater number of pus cells in the female specimens-up to 23 cells /c.mm. in the unspun group, and $8 / \mathrm{c} . \mathrm{mm}$. in the spun group. 11 of the 20 female specimens contained no pus cells (55\%). Pus cell counts in the 12 swabbed female infants revealed a drop in numbers, the highest count being $2 / \mathrm{c} . \mathrm{mm}$.: 10 specimens in 12 (unspun group) and 4 specimens in 6 (spun group) showed no pus cells at all. Careful swabbing of the perineum in the female infant removes the cellular vulvo-vaginal secretions: when pus cell counts are compared in the male and swabbed female infants, the numbers in both sexes are comparable and are low (not more than $3 /$ c.mm.).

The numbers of round cells, if confused with pus cells, could easily make a difference to the diagnostic significance of the counts, since 15 out of 25 males $(60 \%)$ and 25 out of 32 females $(78 \%)$ had varying numbers of round epithelial cells in their urinary specimens.

Where urinary volumes were related to cell counts, it was found that an inverse ratio existed only in the female specimens, and that the small volumes of urine produced high squame counts, thus confirming the impression that urinary specimens are 'contaminated' by vulvo-vaginal secretion. Similarly, the increase in squame counts in the female specimens coincided with high pus cell counts, thus confirming the impression that the vulvo-vaginal secretions were an important source of the pus cells as well.

There were no significant differences between paired spun and unspun specimens with regard to pus cell counts (Gadeholt, 1964), or round epithelial cell counts: there was, however, a tendency for squames to be lost after spinning.

\section{Conclusion}

Difficulties associated with the recognition of pus cells in the urine of newborn infants stem from the variations in morphology of the pus cells, as well as from inability to recognize and differentiate cells other than pus cells. Another confusing factor is the influence of the cellular vulvo-vaginal secretions on the counting of cells. The method of recognizing pus cells, without staining, has simplicity to commend it. Collections from female infants must always be preceded by careful and thorough swabbing of the perineum. Pus cell counts up to $3 / \mathrm{c} . \mathrm{mm}$. may be regarded as normal.

\section{Summary}

Cells in urine can reliably be distinguished by microscopy, without staining. 
In normal newborn infants, urines passed within 36 hours of birth show a maximum of 3 pus cells/ c.mm. in males and $2 / \mathrm{c} . \mathrm{mm}$. in females (if the vulva and perineum have been thoroughly swabbed).

Small round epithelial cells, if erroenously included in a pus cell count, completely invalidate the use of urinary cell counts for the diagnosis of urinary tract infection.

\section{REFERENCES}

Butterworth, S. (1966). The Morphology of the Formed Elemęnts in the Urine. M.D. Thesis, Cambridge.

Gadeholt, H. (1964). Quantitative estimation of urinary sediment, with special regard to sources of error. Brit. med. F., 1, 1547.
James, U. (1959). Urinary infection in the newborn. Lancet, 2 1001.

Kass, E. H. (1956). Asymptomatic infection of the urinary tract. Trans. Ass. Amer. Phycns, 69, 56.

McLeod, J. A., and McLeod, J. W. (1959). Oscillation of the intraleucocytic granules as a criterion of survival of the leucocyte and of the potency of cytotoxic agents. F. Path. Bact., 77, 219.

Michie, A. J. (1959). Paediatric urology-summary of a round table. Pediatrics, 24, 1118.

Prescott, L. F., and Brodie, D. E. (1964). A simple differential stain for urinary sediment. Lancet, $2,940$.

Stansfeld, J. M. (1962). The measurement and meaning of pyuria. Arch. Dis. Childh., 37, 257.

—, and Webb, J. K. G. (1953). Observations on pyuria in children. ibid., 28, 386.

Straffon, R. A., and Engel, W. J. (1960). Diagnosis and treatment of urinary tract infection in children. $\mathcal{F}$. Amer. med. Ass., 174, 1377. 